\title{
XCII. $\mathrm{CO}_{2}$ UTILIZATION DURING THE DISSIMILATION OF GLYCEROL BY THE PROPIONIC ACID BACTERIA ${ }^{1}$
}

\author{
BY ALLEN SPENCER PHELPS, MARVIN JOYCE JOHNSON \\ AND W. H. PETERSON \\ From the Departments of Biochemistry and Agricultural Bacteriology, \\ University of Wisconsin, Madison, Wisconsin, U.S.A.
}

(Received 27 March 1939)

WooD \& WERKMAN [1936] reported that propionic acid bacteria reduced $\mathrm{CO}_{2}$ (obtained from $\mathrm{CaCO}_{3}$ ) during the dissimilation of glycerol. They found that the amount of $\mathrm{CO}_{2}$ present following fermentation was much less than the amount that had been added as $\mathrm{CaCO}_{3}$. They also found that the total organic $\mathrm{C}$ content of the fermented culture was greater than the total organic $\mathrm{C}$ content of the unfermented medium [Wood \& Werkman, 1938]. These were the first reports concerning such an unusual metabolic reaction of the propionic acid bacteria. Barker [1936] and van Niel [1937] seemed reluctant to accept, without confirmation, the original report regarding the propionic acid bacteria. However, the later evidence presented by Wood \& Werkman [1938] should remove all doubts.

During the course of other work upon the propionic acid bacteria an indication of $\mathrm{CO}_{2}$ utilization was noted and the more carefully controlled experiments recorded here were performed. In view of the unusual nature of this reaction, the controversial interest accorded the first reports and the desirability, as suggested by Wood \& Werkman, of confirmation by other laboratories, it seemed worth while to report these results.

\section{EXPERIMENTAL \\ Cultures, medium and methods}

The cultures were Propionibacterium pentosaceum, $P_{11}$ (van Niel's 4 and Wood \& Werkman's $49 \mathrm{~W}) ; P$. technicum, $\mathrm{P}_{12}$ (van Niel's 22); and P. shermanii, $\mathrm{P}_{19}$ (Wood \& Werkman's $52 \mathrm{~W}$ ).

The medium contained $20 \mathrm{~g}$. glycerol, $20 \mathrm{~g}$. $\mathrm{CaCO}_{3}, 500 \mathrm{ml}$. yeast water, ${ }^{2}$ and distilled water to make 1 l. Equivalent amounts of sterile $\mathrm{CaCO}_{3}$ were added to the flasks just before inoculation. A $3 \%$ inoculum of washed $48 \mathrm{hr}$. cells from a glucose-yeast water medium was used. Air in the system was displaced with $\mathrm{O}_{2}$-free $\mathrm{N}_{2}$ immediately after inoculation. These fermentations were incubated at $30^{\circ}$ for 28 days.

The residual glycerol, following extraction from the culture medium, was determined by the method of Woolley (unpublished) which is a modification of the method of Wagenaar [1911]. $\mathrm{CO}_{2}$ was determined on both the culture and a sterile control. The $\mathrm{CO}_{2}$ produced during fermentation and that liberated by

1 Supported in part by a grant from the Wisconsin Alumni Research Foundation. Published with the approvial of the Director of the Wisconsin Agricultural Experiment Station.

2 The clear extract from $200 \mathrm{~g}$. pressed yeast autoclaved in 11 . water. 
acidification with $\mathrm{H}_{3} \mathrm{PO}_{4}$ and removed by aeration at the end of the fermentation was absorbed in $\mathrm{KOH}$ solution. The residual $\mathrm{KOH}$ was titrated after the addition of an excess of $\mathrm{BaCl}_{2}$. The $\mathrm{CO}_{2}$ utilized during the fermentation was then equivalent to the $\mathrm{CO}_{2}$ from the $\mathrm{CaCO}_{3}$, as determined from the control flask, minus the $\mathrm{CO}_{2}$ from the fermentation flask. Volatile acids, propionic and acetic, were determined by a modified Duclaux distillation after steam distillation from an acidified $(p \mathrm{H} 2)$ aliquot of the culture. The non-volatile acids, lactic and succinic, were removed from the residue of the volatile acid distillation by continuous extraction with ethyl ether. Lactic acid was determined by the method of Friedemann \& Graeser [1933] and succinic acid by the following modification of the method of Moyle [1924]. An acidified aliquot of the residue of the volatile acid distillation, containing 10-75 mg. succinic acid, was extracted with ethyl ether for $24 \mathrm{hr}$. The extract was taken up in 30-40 ml. water containing $1 \mathrm{ml}$. $95 \% \mathrm{H}_{2} \mathrm{SO}_{4}$, heated and $0 \cdot 1 \mathrm{~N} \mathrm{KMnO}_{4}$ added until a permanent brown precipitate appeared in the boiling solution. This oxidation destroyed the lactic acid. The solution was evaporated to a convenient volume, cooled and extracted with ethyl ether for $24 \mathrm{hr}$. The extract was taken up in 15-20 ml. water and $5 \mathrm{ml}$. $10 \% \mathrm{AgNO}_{3}$ added. This solution was adjusted to $p \mathrm{H} 6 \cdot 0-6.5$ with $0.5 \mathrm{~N} \mathrm{NH}_{4} \mathrm{OH}$ and bromocresol purple (other indicators in this range are unsatisfactory), filtered on a Gooch crucible, and washed with four or five $3 \mathrm{ml}$. portions of $50 \%$ alcohol. The precipitate was dissolved with two $10 \mathrm{ml}$. portions of hot $1: 4 \mathrm{HNO}_{3}$, cooled, and titrated with $0.07 N$ KCNS and saturated ferric alum indicator. Two mol. of KCNS are equivalent to one mol. of succinic acid. Recovery of known samples averaged $98-99 \%$.

\section{RESULTS}

The data are recorded in Table I. Uniformly the principal course of the reaction has been the production of propionic and succinic acids accompanied by small amounts of acetic and lactic acids. In each fermentation there has been

\section{Table I. Glycerol dissimilation by the propionic acid bacteria}

\begin{tabular}{|c|c|c|c|c|c|}
\hline Culture No. & $\mathbf{P}_{11}$ & $\mathbf{P}_{11}$ & $\mathbf{P}_{\mathbf{1 2}}$ & $\mathbf{P}_{12}$ & $\mathbf{P}_{19}$ \\
\hline Glycerol fermented mM. per 1 . & $205 \cdot 3$ & $212 \cdot 8$ & $183 \cdot 9$ & $186 \cdot 5$ & $92 \cdot 5$ \\
\hline $\mathrm{CO}_{2}$ utilized per $100 \mathrm{mM}$. fermented glycerol & $21 \cdot 40$ & $25 \cdot 6$ & $9 \cdot 22$ & $14 \cdot 36$ & $25 \cdot 41$ \\
\hline \multicolumn{6}{|l|}{ Products per $100 \mathrm{mM}$. fermented glycerol } \\
\hline $\begin{array}{l}\text { Propionic acid } \\
\text { Acetic acid } \\
\text { Succinic acid } \\
\text { Lactic acid }\end{array}$ & $\begin{array}{r}75 \cdot 50 \\
2 \cdot 92 \\
23 \cdot 60 \\
-\end{array}$ & $\begin{array}{r}70 \cdot 00 \\
8 \cdot 75 \\
23 \cdot 78 \\
-\end{array}$ & $\begin{array}{r}87 \cdot 14 \\
0 \cdot 92 \\
9 \cdot 90 \\
0 \cdot 27\end{array}$ & $\begin{array}{r}90 \cdot 07 \\
0 \cdot 99 \\
13 \cdot 21 \\
0 \cdot 99\end{array}$ & $\begin{array}{r}66 \cdot 26 \\
5 \cdot 84 \\
25 \cdot 48 \\
0 \cdot 70\end{array}$ \\
\hline \multicolumn{6}{|l|}{ C recovery $(\%)$} \\
\hline $\begin{array}{l}\text { Basis, glycerol plus } \mathrm{CO}_{2} \\
\text { Basis, glycerol }\end{array}$ & $\begin{array}{l}101 \cdot 8 \\
108 \cdot 9\end{array}$ & $\begin{array}{r}99 \cdot 2 \\
107 \cdot 5\end{array}$ & $\begin{array}{r}98 \cdot 2 \\
101 \cdot 2\end{array}$ & $\begin{array}{l}104 \cdot 2 \\
109 \cdot 3\end{array}$ & $\begin{array}{r}96 \cdot 7 \\
105 \cdot 0\end{array}$ \\
\hline \multicolumn{6}{|l|}{ Oxidation-reduction index } \\
\hline $\begin{array}{l}\text { Basis, glycerol plus } \mathrm{CO}_{2} \\
\text { Basis, glycerol }\end{array}$ & $\begin{array}{l}1 \cdot 04 \\
1 \cdot 64\end{array}$ & $\begin{array}{l}1 \cdot 02 \\
1 \cdot 77\end{array}$ & $\begin{array}{l}1 \cdot 04 \\
1 \cdot 26\end{array}$ & $\begin{array}{l}0.95 \\
1 \cdot 26\end{array}$ & $\begin{array}{l}1 \cdot 05 \\
1 \cdot 89\end{array}$ \\
\hline
\end{tabular}

a definite utilization of $\mathrm{CO}_{2}$, a fact which may be demonstrated in several ways. The strongest evidence appears in the $\mathrm{CO}_{2}$ determinations. In every case the total $\mathrm{CO}_{2}$ remaining in the flask and absorber following fermentation is less than the amount of $\mathrm{CO}_{2}$ originally added as $\mathrm{CaCO}_{3}$. In the fermentation showing the smallest $\mathrm{CO}_{2}$ utilization the observed difference in $\mathrm{CO}_{2}$ concentrations is some 25 times the experimental error; in other fermentations the observed $\mathrm{CO}_{2}$ uptake is well over 100 times the experimental error.

Biochem. 1939 xxxm 


\section{A. S. PHELPS, M. J. JOHNSON AND W. H. PETERSON}

Supplementary evidence is offered by the $\mathrm{C}$ recoveries and the oxidationreduction indices. When the $\mathrm{C}$ recoveries are based upon glycerol alone they are uniformly high, for the $\mathrm{C}$ content of the products is greater than the $\mathrm{C}$ content of the glycerol fermented. However, when the $\mathrm{C}$ recoveries are based upon glycerol plus $\mathrm{CO}_{2}$ the values approach $100 \%$. The oxidation-reduction indices indicate a large excess of oxidized products when calculated upon the basis of glycerol alone. However, if the utilized $\mathrm{CO}_{2}$, an oxidized compound, is entered in these calculations, the oxidation-reduction indices approach the ideal value of 1.00 .

In each of these fermentations, as in most of those reported by Wood \& Werkman, the succinic acid is, on a molar basis, approximately equal to the $\mathrm{CO}_{2}$ utilized.

\section{SUMMARY}

The report of Wood \& Werkman that the propionic acid bacteria utilize $\mathrm{CO}_{2}$ during the dissimilation of glycerol has been confirmed.

\section{REFERENCES}

Barker (1936). Arch. Mikrobiol. 7, 404.

Friedemann \& Graeser (1933). J. biol. Chem. 100, 291.

Moyle (1924). Biochem. J. 18, 351.

van Niel (1937). Ann. Rev. Biochem. 6, 595.

Wagenaar (1911). Pharm. Weekbl. 48, 497.

Wood \& Werkman (1936). Biochem. J. 30, 48.

- (1938). Biochem. J. 32, 1262. 